\title{
Factors Influencing for Early Retirement Demand of School Principals in Riyadh Educational Directorates, Saudi Arabia
}

\author{
Hamed Bin Ibrahim Al-Manea \\ Community College, Huraimla, Shaqra University, Saudi Arabia
}

\begin{abstract}
The present study explored the factors influencing for early retirement demand of school principals in Riyadh educational directorates, Saudi Arabia. The study population consists of government primary, middle and secondary schools principals in Riyadh (198). The study methodology used questioner and descriptive approach as tools for data collection. The results showed that school principals of primary, middle and secondary schools in Riyadh Educational Directorates, Saudi Arabia have held out that the job factors are the biggest motives behind seeking early retirement on their part. Second in importance come the economic, personal, psychological and social factors. Significant statistical differences, 5\%, have been recorded in the study sample point of view regarding economic and social factors as well as those attributed to the job conditions, all of which motivate school principals to demand early retirement. There is a significant statistical difference among school principals attributed to the type of educational stage when studying economic factors. Significant statistical difference, 5\%, in the study responders' point of view have emerged concerning psychological, social, health and personal factors stimulating school principals in Riyadh educational directorates to seek early retirement. These factors are attributed to the variable of educational qualifications. Meaningful statistical differences, 5\%, in the study responders' opinions related to social, health and personal factors affecting the school principals early retirement in Riyadh educational directorates have been shown. These factors are attributed to the school management years of experience variable.
\end{abstract}

Keywords: Early retirement, school principals, personal factors, psycho-factors, social factors.

\section{Introduction}

Management leaders including school principals are among the pillars of educational process. A principal is the person officially appointed in a school to take up all administrative and technical responsibilities there. A principal is keen on creating an atmosphere of harmony and trust [1-2]. Principals face administrative problems as well as educational ones. There are factors that affect principals' management and technical performance, as well as an overload of other tasks. They are also lacking the skills necessary to evaluate teachers' performance [3]. Despite the fact that they are entrusted with powers to run the administrative work inside their schools, yet there are obstacles as to delegating powers of education departments such as lack of clear policies to determine administrative responsibilities, material resources etc. Moreover, education department officials underestimate the problems emerging from lack of delegation of administrative powers necessary. Officials in education department have no faith in the effectiveness of delegation [4]. All these obstacles as well as other psychological pressures facing principals due to occupational overburdens sometimes push some of them to be more inclined to early retirement [5].

Occupational, administrative, social, family, personal, psychological and material factors are the most important causes of those working in the field of education and teachers in particular to apply for an early retirement [5-10]. An individual's decision, to go for an early retirement, means to degrade his/her own social status such as depriving him/herself from financial benefits due to his/her position as well as the influence related to his/her status [11].

\subsection{Study Problem}

The increasing number in early retirement of principals of the three stages of education has denied education process principals who gained experience over long years that are hard to recover simply by promoting others to their positions. The phenomena need a study to explore the motives behind their decision to quit. The study will shed a light on the phenomena of early retirement among principals as being an economic and social loss that 
should be considered and probed. Moreover, those experts in education are human resources crucial to the comprehensive educational and social development Saudi Arabia seeks to attain for the well-being of the society and its development. The study is designed to answer the following sub-questions:

- What are the most important psychological factors influencing principals' decision to apply for an early retirement in Riyadh Education Department?

- What are the most important economic factors influencing principals in Riyadh Education Department to apply for early retirement?

- What are most important occupational factors influencing the decision of principals in Riyadh Education Department to seek an early retirement?

- What are the most important social factors affecting the decision of school principals in Riyadh Education Department to apply for early retirement?

- What are the most important health factors the pushed school principals in Riyadh Education Department to apply for early retirement?

- What are most important personal factors influencing the decision of principals in Riyadh Education Department to seek an early retirement?

- To what extent did the sample vary in its responses to the different variants of the study? (Education stages, qualifications, years of experience in school management.)

\subsection{Importance of the Study}

The importance of the study centers on the following points:

1. Providing officials in different education department in the kingdom with a real vision for improving overall education process.

2. Contributing to a clear perspective of the important factors resulting in early retirement applications and thus helping to avert them in the future.

3. The study provides information necessary to help taking more effective decisions in this respect.

\subsection{Objectives}

The objective of the study is to pinpoint factors influencing school principals in Riyadh Education Department to apply for early retirement.

- Determining the most important psychological factors influencing principals' decision to apply for an early retirement in Riyadh Education Department.

- Investigating the most important economic factors influencing principals in Riyadh Education Department to apply for early retirement.

- Pinpointing the most important occupational factors influencing the decision of principals in Riyadh Education Department to seek an early retirement.

- Determining the most important social factors affecting the decision of school principals in Riyadh Education Department to apply for early retirement.

- Showing the most important health factors pushed school principals in Riyadh Education Department to apply for early retirement?

- Investigating the most important personal factors influencing the decision of principals in Riyadh Education Department to seek an early retirement?

- Unveiling the extent of discrepancy in the sample's responses to the different variants of the study. (Education stages, qualifications, years of experience in school management).

\subsection{Literature review}

School management is the smallest and most important administrative form in educational system. It carries out educational policies and objectives. It is the frontal side of the education system and in direct contact with the society [12]. According to Jordan [13], it is the culmination of efforts exerted in different ways and through which human and material resources are directed to meet the objectives of the educational community. It is defined by Abdulrahman [14] as translating the activities of a group of school employees into a common goal by 
organizing and coordinating those activities. It is also defined by Solaiman [15] as an organized whole that react positively inside and outside the school according to the state's general policies and educational philosophy with the aim of preparing the younger generation to meet the objectives of the society and the common interest of the state. This necessitates carrying out a set of coordinated works and activities and creating a favorable atmosphere to make them a success.

The school management is responsible for executing the policies and objectives of educational department. As school management is responsible for achieving the school message through its direct contact with students, it enjoys greater freedom in action to carry out its roles and take decisions and thus it has turned into the most important administrative unit in education administration and has the most prominent status in terms of management [16].

According the $\mathrm{Al}$ Waseet Dictionary, retirement of an employee means to go on pension. It is one of the newly introduced entries in Arabic dictionaries [17]. Despite the fact that scholars and specialists have not agreed on unified concept of retirement, yet they agreed on several aspects related to retirement such as retirement is more associated with occupation rather than work. A retired person leaves his job at a certain age regardless of this ability to work. Retirement is also linked to other social roles. Moreover retirement could be obligatory or voluntary [18]. According to Al Ghareeb [18] early retirement is defined as individual's decision to terminate his carrier before reaching a certain age set by the law for social, psychological, occupational, material or health reasons.

Al Jaber and Al Hudhod [19] tried to probe the phenomena of retirement of Kuwaiti female teachers and their motivations. The study was based on a sample of (89) Kuwaiti female teachers who preferred early retirement. A questionnaire took up the changes related to the teacher's personality, economic, social, administrative and occupational conditions that promoted Kuwaiti female teacher to press for early retirement. The study reads that the most important factors related to the early retirement phenomena are social status, the subjects taught family's average income and qualifications. Administrative and occupational conditions such as lack of material and moral incentives, the management method applied and other related conditions also got Kuwaiti female teachers to apply for early retirement rather than personal ones.

Al Metari's study [20] was designed to explore employees' inclination as to early retirement as stipulated in Saudi civil service system for those who occupy public ranks from the first to the fifteenth. To achieve the goal of the study, he relied on the descriptive methodology through a sample of employees and documentation by referring to records and documents of civil service to get the number of retirees. He also resorted to theoretical framework by reviewing relevant previous studies. The study also relied on a questionnaire to collect data. The study concluded that the majority of state employees agree that early retirement has several benefits such as providing job opportunities, alleviating unemployment problem, helping in getting rid of disguised unemployment in government bodies as well as giving more employees the opportunity for promotion.

Al Meshari (1432) study unveiled the tendencies of civil sector employees as to retirement plans and relevant factors as well as the anticipated returns from retirement plans and life after retirement. The researcher adopted a social survey as the methodology of his study and a questionnaire to collect data necessary for the study. The study concluded that fear of losing the long years of experience or rising tension at home or outside with colleagues at workplace are among the most prominent factors affecting retirement plans. In light of these results the researcher recommended the following: drawing plans and problems to scale down problems facing retirees and training public and private sector employees on skills of retirement planning and the importance of planning for retirement and its role in securing the future.

Al Dous [21] attempts to answer the question: What is the relation between work pressure and the inclination of secondary school female teacher in Riyadh to apply for early retirement? He finds a direct relation between sources of work pressure and intendancy to press for an early retirement. The study concluded that there is a direct relation between work pressure and tendency to apply for early retirement.

\section{Methodology and Procedures}

A descriptive methodology was adopted based on a field study which provides a detailed quantitative and qualitative description as well as investigation and analysis of features of a phenomenon. 


\subsection{Study Tools and Data Gathering}

A questionnaire is prepared in light of the results of previous studies on elements affecting Saudi school principals applying for early pension. The questionnaire is used to gather necessary data to realize study objectives. The questionnaire is divided into two parts: first: study variables, namely education stage, qualifications and experience in school administration. The second part consists of the elements affecting school principals to apply for early pension; covering six axes: psychological, economic, occupational, social, health and personal elements. Each axis has five phrases with a fivedegree scale according to its importance (totally agree, agree, sometimes, disagree, and totally disagree). These responses have quantitative degrees $(1,2,3,4,5)$. The questionnaire has the total of 30 phrases and after extracting average of all responses, a standard was set to judge the importance of the responses.

\subsection{Description of study sample}

Description of study sample is depicted in Table (1) for education stage, in Table (2) for educational qualifications and in Table (3) for experience at school administration. However, Table (1) illustrates that the majority of the sample are primary school principals (49.5\%), then prep. school principals (31.3\%) and high school principals (19.2\%). In addition, Table (2) illustrates that the majority of the sample are bachelor holders (75.8\%), then master holders (11.1\%), then other qualifications (8.1\%) and $\mathrm{PhD}$ holders $(5.1 \%)$ and Table (3) illustrates that most of the sample individuals has 15-20 year experience. This element is very important to take the early retirement decision, since the more experience the more occupational maturity is.

TABLE I: Distribution of sample individuals according to education stage

\begin{tabular}{|l|c|c|}
\hline Age & Frequency & Percentage (\%) \\
\hline Primary school principals & 98 & 49.5 \\
\hline Preparatory school principals & 62 & 31.3 \\
\hline High school principals & 38 & 19.2 \\
\hline Total & 198 & 100 \\
\hline
\end{tabular}

TABLE II: Distribution of sample individuals according educational qualifications

\begin{tabular}{|c|c|c|}
\hline Educational qualification & Frequency & Percentage (\%) \\
\hline PhD & 10 & 5.1 \\
\hline Masters & 22 & 11.1 \\
\hline Bachelor & 150 & 75.8 \\
\hline Other & 16 & 8.1 \\
\hline Total & 198 & 100 \\
\hline
\end{tabular}

TABLE III: Distribution of sample individuals according to experience at school administration

\begin{tabular}{|l|c|c|}
\hline Years of experience & Frequency & Percentage (\%) \\
\hline Less than 5 years & 28 & 14.1 \\
\hline 5-10 years & 54 & 27.3 \\
\hline 15-20 years & 84 & 42.4 \\
\hline More than 20 years & 32 & 16.2 \\
\hline Total & 198 & 100 \\
\hline
\end{tabular}

\section{Results and Discussion}

\subsection{Answer to the first question: What are the most important psychological elements affecting school principals' applications for early retirement in Riyadh educational Department?}

To answer this question averages and standard deviations were used to order psychological elements according to the sample's degree of approval. According to principals' responses, the psychological elements had a medium approval with the average of (3.19). The highest average was 3.64 and the lowest was 2.72 with the difference is 0.92 which indicates a high spread of the questionnaire's responses. 
3.2Answer to the second question: what are the most important economic elements affecting school principals' application for early retirement?

To answer this question, averages and standard deviations were used to order economic elements according to the sample's degree of approval. The average was between 1.89 and 4.64.

3.3Answer to the third question: what are the most important occupational elements affecting school principals' applications for early retirement?

To answer this question, averages and standard deviations were used to order occupational elements according to the sample's degree of approval. The average was between 4.20 and 3.25.

3.4Answer to the fourth question: what are the most important social elements affecting school principals' applications for early retirement?

To answer this question, averages and standard deviations were used to order social elements according to the sample's degree of approval. The average was between 2.23 and 3.05.

3.5Answer to the fifth question: what are the most important health elements affecting school principals' applications for early retirement?

To answer this question, averages and standard deviations were used to order health elements according to the sample's degree of approval. The average was between 4.11 and 3.19.

3.6Answer of the sixth question: what are the most important personal elements affecting school principals' applications for early retirement?

To answer this question, averages and standard deviations were used to order personal elements according to the sample's degree of approval. The average was between 2.27 and 3.72.

3.7Answer to the seventh question: Are there any statistically significant differences at the 5\% level according to the sample based on the variables of educational stage, qualifications and school administration years of experience?

To point out the statistical differences among averages of educational stage, analysis of variance was used on study axes. The result was of no significant statistical difference at the $5 \%$ level on the educational variable at the axes of psychological, health and personal elements.

\section{Conclusion}

Early retirement is a real phenomenon that cannot be ignored as it grew and affected various sectors including education. After it had been confined to teachers only, it expanded to include top educational management, and thus had an impact on the educational process in general due to experience wasted. Solutions should be probed to scale down the number of early retirement application as the ministry of education is suffering from this phenomenon. This study is trying to discuss early retirement of school principals at the three educational stages (primary, preparatory and high school) in Riyadh educational department. Numbers of principals applying for early retirement are steadily growing lately and to the extent of the researcher's knowledge, this is the first study to take up this issue.

This study aimed at identifying elements affecting application for early retirement and its relevant variables: educational stage, qualifications and years of experience in school administration. To answer research questions a descriptive methodology was followed. A questionnaire was designed and used on a sample of Riyadh school principals. Retrieved and valid questionnaires were (198) and after statistical analysis of study questions, the following conclusions were reached: 
1. Occupational elements were the most prominent in applying for early retirement, then health, economic, personal, psychological and social ones.

2. There are statistically significant differences (5\%) affecting the sample in occupational and social elements due to difference in the variable of educational stage.

3. There are statistically significant differences (5\%) affecting the sample in psychological, health and personal elements due to the difference in the variable of qualifications.

4. There are statistically significant differences $(5 \%)$ according to the sample in social, health and personal elements affecting the sample due to difference in the variable of experience in school administration.

5. Personal elements were significantly connected to health ones which were also connected to psychological ones. The least connection was between social and psychological elements. There were no inverse or no moral relationships among elements under study.

\section{Recommendations}

According to the study and its results, the following recommendations were provided to limit applications of Saudi school principals for early retirement:

- Paying closer attention to Saudi school principals' health, occupational, psychological, social and personal positions.

- Defining occupational description of school principals to achieve objectives of educational process.

- Providing financial incentives to school principals to give them more satisfaction compared to other civil jobs.

- Rising school principals' social status during duty by improving their occupational, psychological, personal, social and economic positions. Introducing them to the negative impacts of early retirement on the educational process.

- Providing them with a good working environment and giving them more knowledge and skills. Resolving problems of school administration and limiting their responsibilities in order to enable them to work under favorable conditions.

\section{References}

[1] M. F. A. K. Beni Mousa, "Principals' Vision of Technical and Management Facing Government Schools in Jarash," unpublished MA thesis, Yarmouk University, Irbid, Jordan, 1995. (In Arabic).

[2] M. A. S.Al Saleh, "Humanitarian Practices of Preparatory School Principal as Seen by teachers of state-owned and private schools in Riyadh," unpublished MA thesis, Faculty of Education, King Saud University, KSA (2002). (In Arabic).

[3] A. A. Al Uwayridi, "Most Important Factors Affecting Performance of Preparatory Schools in Riyadh," Education Dept. unpublished MA thesis, Faculty of Education, King Saud University, KSA, 1418H. (In Arabic).

[4] S. I. Al Zamel, "Determining Powers of School Management (field study of obstacles to delegating powers of education department to school management," unpublished MA thesis, King Saud University, KSA, 1998. (In Arabic).

[5] T.Al Badri, "Leadership \& Administrative Methods in Educational Institutions," $2^{\text {nd }}$ edition, Amman, Dar Al Fikr, 1993. (In Arabic).

[6] K. A. Al Shalal, "Main Reasons behind Early Retirement Phenomena Among Kuwaiti Employees: Sociological Analytical Study," Social Sciences Magazine, vol. 24, pp.135-185,1996 a. (In Arabic).

[7] K. A. Al Shalal, "Relations between Vocational Satisfaction and Early Retirement among Employees," Arab Magazine for Humanities Sciences, vol.56, pp.110-171,1996 b. (In Arabic).

[8] S. A. S. Al Ghamdi, "Teachers' Early Retirement Tendency in Mecca \& Its Relation to Changes," Unpublished MA Thesis, Psychology Dept. Faculty of Education, Umm Al-Qura University, KSA,1421H. (In Arabic).

[9] B.Al Ammari, "Early Retirement Phenomena of Qatari Female Teachers in Public Schools in Qatar: Factors and Relevant Changes," Education Sciences Magazine, vol. 11, pp.15-51, 2007. (In Arabic).

[10] B. M. A. Sama'anah, "Inclination of Government Secondary School Teachers in Northern West Bank, Palestine as to Early Retirement \& Its Influences," unpublished MA in education management, Higher Studies College in An-Najah National University, Nablus, Palestine, 2008. (In Arabic). 
[11] M. S. Al Meshari, "Retirement Planning for Employees of Different Sectors: A field study on state-owned civil sector in Hotat Bani Tamim Governorate," Unpublished MA thesis, Social Services Dept., Faculty of Social Sciences, Imam Muhammad ibn Saud Islamic University, KSA ,1432H. (In Arabic).

[12] A. E. A.Saleh, "Management Problems in Private Schools from Perspective of Principals, Teachers, Parents, Students in Northern Palestine Governorate," Unpublished MA thesis in education management, Higher Studies College in AnNajah University in Nablus, Palestine, 2004. (In Arabic).

[13] K.F. Jordan, " School Business Administration". New York: The Ronald Press Company,1969.

[14] H.Abdulrahman, "Education Management, Researches and Studies," Al Tawfeek Printing House, Amman, Jordan ,1979. (In Arabic).

[15] A. A. Solaiman, "School Management in Light of Modern Islamic Administrative Though," Anglo Library, Cairo, 1987. (In Arabic).

[16] I.M. Abo Farwa, "School Management, Open University," West Tripoli ,1997. (In Arabic).

[17] M.Ben Senitan, "Retirement, Arab Centre for Security Studies," Riyadh, Saudi Arabia, 1993. (In Arabic).

[18] A. A. Al Ghareeb, "Retirement Department As A Foundation for Practicing Social Services Jobs," Cooperation Magazine, vol. 48,pp.177-238, 1998. (In Arabic).

[19] Z. A. Al Jaber, and D. A. Al Hudhod, "Phenomena of Kuwaiti Female Teachers' Retirement \& its Reasons: A Field Study, "King Saud University Magazine, Vol. 3, Education Sciences (1),pp.359-399. 1991. (In Arabic).

[20] D. U. A. Al Metari, "Civil Servants Inclination to Early Retirement in Saudi Civil Service System: Field Study," Unpublished MA thesis, College of Business Administration, King Saud University, KSA, 1426H. (In Arabic).

[21] G. M. S. Al Dous, Work Pressure \& Inclination of Riyadh Secondary School Female Teachers to Early Retirement," unpublished MA thesis, Administrative Sciences Depart., Naif Arab University for Security Sciences, KSA, 1434 H. (In Arabic). 